\title{
An Overview of Naturally Occurring Radioactive Materials (NORM) in the Petroleum Industry
}

by K.P. Smith

Environmental Assessment and Information Sciences Division, Argonne National Laboratory, 9700 South Cass Avenue, Argonne, Illinois 60439

Work sponsored by United States Department of Energy, Office of Domestic and International Energy Policy 


\section{CONTENTS}

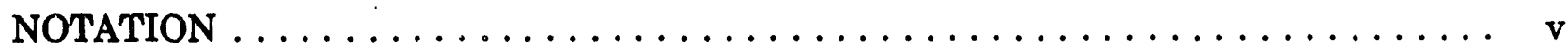

ACKNOWLEDGMENTS $\ldots \ldots \ldots \ldots \ldots \ldots \ldots \ldots \ldots \ldots \ldots \ldots \ldots$ vii

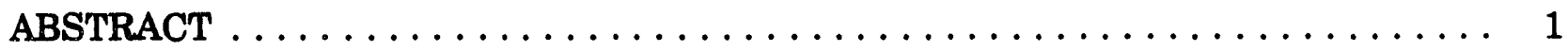

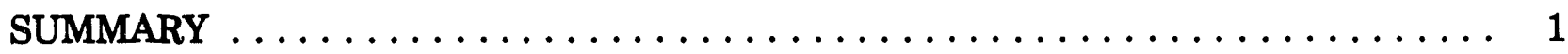

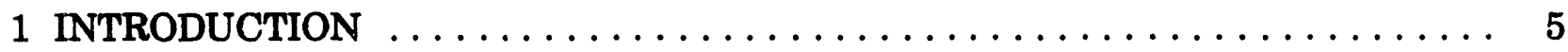

1.1 Origins of NORM in Oil and Gas Wastes $\ldots \ldots \ldots \ldots \ldots \ldots \ldots$

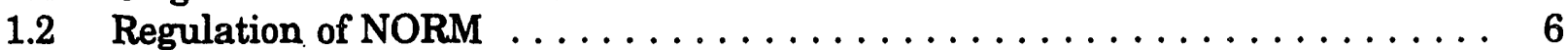

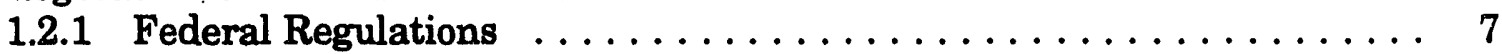

1.2 .2 Congressional Activity . . . . . . . . . . . . . . . . . 10

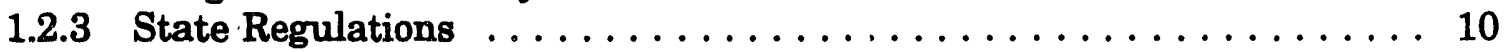

2 ACCUMULATION OF NORM IN OIL AND GAS WASTES . . . . . . . . . . 12

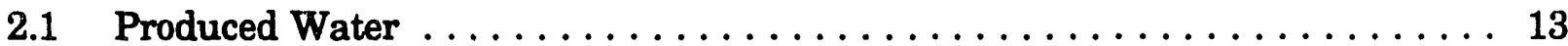

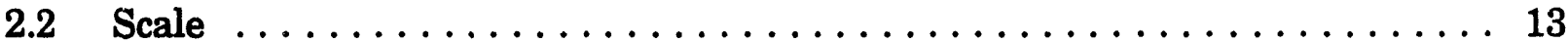

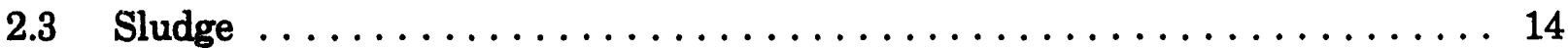

2.4 Production and Processing Equipment $\ldots \ldots \ldots \ldots \ldots \ldots \ldots \ldots$

3 GEOGRAPHIC DISTRIBUTION OF NORM $\ldots \ldots \ldots \ldots \ldots \ldots \ldots$

4 NORM MANAGEMENT AND DISPOSAL OPTIONS $\ldots \ldots \ldots \ldots \ldots \ldots$

4.1 Produced Water $\ldots \ldots \ldots \ldots \ldots \ldots \ldots \ldots \ldots \ldots \ldots \ldots$

4.2 Scale and Sludge $\ldots \ldots \ldots \ldots \ldots \ldots \ldots \ldots \ldots \ldots \ldots \ldots \ldots \ldots$

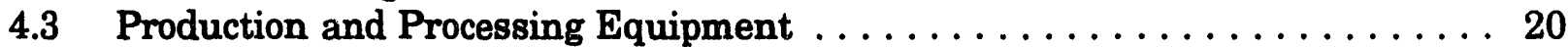

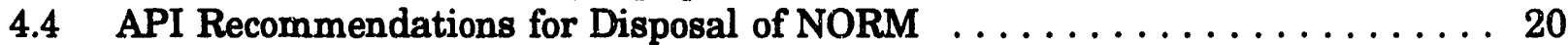

4.5 Treatment and Minimization of NORM-Contaminated Wastes . . . . . . . . 21

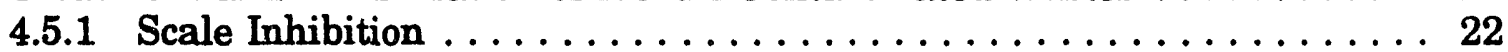

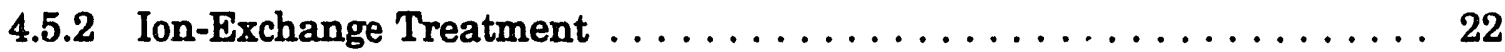

4.5.3 Volume-Reduction Treatment ................... 23

5 FATE, TRANSFER, AND RISK ASSOCIATED WITH NORM . . . . . . . . 24

5.1 Environmental Fate and Transfer $\ldots \ldots \ldots \ldots \ldots \ldots \ldots \ldots \ldots \ldots$

5.2 Human Health Risk Assessments . . . . . . . . . . . . . . . . . 25

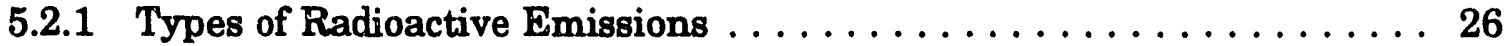

5.2.2 Radiation Exposure Limits ....................... 26

5.2 .3 Radiation Exposure Pathways ................... 26

5.2.4 Radiological Risk Assessment of Disposal Options . . . . . . . . . 27 


\section{CONTENTS (Cont.)}

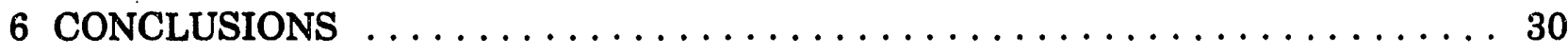

6.1 Additional Research Needs . . . . . . . . . . . . . . . . . . . . 30

6.2 Development of NORM Regulations $\ldots \ldots \ldots \ldots \ldots \ldots \ldots \ldots \ldots \ldots \ldots \ldots$

6.3 Potential Impacts on the Oil and Gas Industry $\ldots \ldots \ldots \ldots \ldots \ldots \ldots . \ldots \ldots$

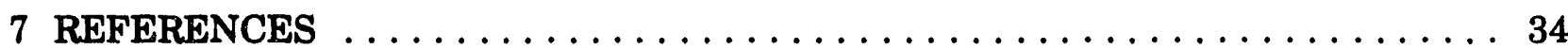

\section{FIGURES}

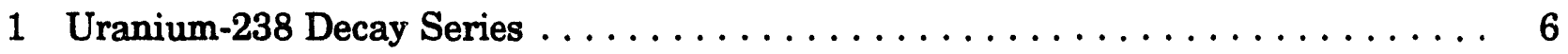

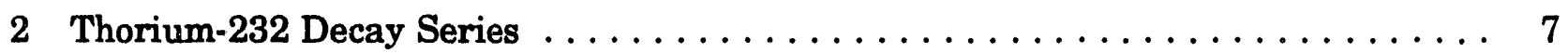

\section{TABLES}

1 Radiation Exposure Levels Associated with NORM in Oil and Gas Production and Processing Equipment . . . . . . . . . . . . . . 15

2 Abbreviations Used in Table 1 to Designate Types of Oil and Gas Production and Processing Equipment . . . . . . . . . . . . . . . 16

3 Maximum Concentration Limits for Disposal of NORM $\ldots \ldots \ldots \ldots \ldots \ldots$ 


\section{NOTATION}

The following is a list of acronyms, abbreviations, and initialisms (including units of measure and chemical symbols) used in this document. Acronyms used in tables only are defined in the respective tables.

\section{ACRONYMS, ABBREVIATIONS, AND INITIALISMS}

$\begin{array}{ll}\text { AEA } & \text { Atomic Energy Act } \\ \text { API } & \text { American Petroleum Institute } \\ \text { BNL } & \text { Brookhaven National Laboratory } \\ \text { CAA } & \text { Clean Air Act } \\ \text { CERCLA } & \text { Comprehensive Environmental Response, Compensation, and Liability Act } \\ \text { CFR } & \text { Code of Federal Regulations } \\ \text { CRCPD } & \text { Conference of Radiation Control Program Directors } \\ \text { CWA } & \text { Clean Water Act } \\ \text { DOE } & \text { U.S. Department of Energy } \\ \text { E\&P } & \text { exploration and production } \\ \text { EOR } & \text { enhanced oil recovery } \\ \text { EPA } & \text { U.S. Environmental Protection Agency } \\ \text { LLW } & \text { low-level radioactive waste } \\ \text { NESHAPs } & \text { National Emissions Standards for Hazardous Air Pollutants } \\ \text { NORM } & \text { naturally occurring radioactive materials } \\ \text { NPDES } & \text { National Pollutant Discharge Elimination System } \\ \text { NRC } & \text { U.S. Nuclear Regulatory Commission } \\ \text { OSHA } & \text { Occupational Safety and Health Administration } \\ \text { RCRA } & \text { Resource Conservation and Recovery Act } \\ \text { SDWA } & \text { Safe Drinking Water Act } \\ \text { TDS } & \text { total dissolved solids } \\ \text { UIC } & \text { Underground Injection Control } \\ \text { USDW } & \text { underground source of drinking water }\end{array}$

\section{UNITS OF MEASURE}

$\begin{array}{ll}\mathrm{cm} & \text { centimeter(s) } \\ \text { count/min } & \text { count(s) per minute } \\ { }^{\circ} \mathrm{F} & \text { degree(s) Fahrenheit } \\ \mathrm{ft} & \text { foot (feet) } \\ \mathrm{h} & \text { hour(s) } \\ \mathrm{in} . & \text { inch(es) } \\ \mathrm{lb} & \text { pound(s) } \\ \mu \mathrm{Ci} / \mathrm{mL} & \text { microcurie(s) per milliliter } \\ \mu \mathrm{R} / \mathrm{h} & \text { microroentgen(s) per hour } \\ \mu \mathrm{rem} / \mathrm{h} & \text { microrem(s) per hour } \\ \mathrm{m}^{2} & \text { square meter(s) } \\ \mathrm{m}^{3} & \text { cubic meter(s) }\end{array}$




$\begin{array}{ll}\mathrm{mg} / \mathrm{L} & \text { milligram(s) per liter } \\ \mathrm{mrem} / \mathrm{yr} & \text { millirem(s) per year } \\ \mathrm{pCi} / \mathrm{g} & \text { picocurie(s) per gram } \\ \mathrm{pCi} / \mathrm{L} & \text { picocurie(s) per liter } \\ \mathrm{pCi} / \mathrm{m}^{2} / \mathrm{s} & \text { picocurie(s) per square meter per second } \\ \mathrm{t} & \text { metric ton(s) } \\ \mathrm{yr} & \text { year(s) }\end{array}$

\section{CHEMICAL SYMBOLS}

$\begin{array}{ll}\mathrm{BaSO}_{4} & \text { barium sulfate } \\ \mathrm{RaSO}_{4} & \text { radium sulfate }\end{array}$ 


\section{ACKNOWLEDGMENTS}

Research for this report was sponsored by the U.S. Department of Energy, Office of Domestic and International Energy Policy, and conducted under the direction of John Gasper, Argonne National Laboratory (ANL), Washington, D.C. The author wishes to acknowledge the assistance of Elizabeth Hocking and Ellen Gross, ANL, Washington, D.C.; David Minnaar, Division of Radiological Health, Michigan Department of Public Health, Lansing, Michigan; and Doug Callon, EXXON Company USA, New Orleans, Louisiana. 


\title{
AN OVERVIEW OF NATURALLY OCCURRING RADIOACTIVE MATERIALS (NORM) IN THE PETROLEUM INDUSTRY
}

\author{
by
}

K.P. Smith

\begin{abstract}
Oil and gas extraction and processing operations sometimes accumulate naturally occurring radioactive materials (NORM) at concentrations above normal in by-product waste streams. Results from NORM surveys indicate that radionuclide concentrations can be quite variable, ranging from undetectable to extremely high levels. To date, efforts to characterize the geographic distribution of NORM have been limited by poor statistical representation. In addition, the fate of NORM in the environment has not been fully defined, and few human health risk assessments have been conducted.

Both the petroleum industry and regulators are becoming increasingly concerned about the presence of NORM. At present, most existing federal environmental regulations do not address oil and gas NORM, and only a few states have developed regulatory programs. Available data suggest that the occurrence of NORM (and associated health risks) is significant enough to warrant increased regulatory control. However, before these regulations can be developed, additional research is needed to (1) better characterize the occurrence and distribution of NORM throughout the industry, (2) quantify hazards posed by NORM to industry workers and the general public, and (3) develop effective waste treatment and minimization technologies that will lower the risk associated with NORM and reduce disposal costs.
\end{abstract}

\section{SUMMARY}

Oil and gas extraction and processing operations sometimes accumulate naturally occurring radioactive materials (NORM) at concentrations above normal in by-product waste streams. Elevated NORM concentrations have been detected in produced water, scale, sludge, and oil and gas production and processing equipment in many geographic regions. Both the petroleum industry and regulators are becoming increasingly concerned about the presence of NORM; however, most existing federal environmental regulations do not address oil and gas NORM, and only a few states have begun to develop NORM regulatory programs. 
The primary radionuclides of concern in oil and gas NORM are radium-226 and radium-228. These isotopes are the decay products of uranium and thorium isotopes that are present in subsurface formations from which hydrocarbons are produced. While uranium and thorium are largely immobile, radium is slightly more soluble and may become mobilized in the fluid phases of the formation. Other radionuclides of concern, particularly in gas processing equipment, are lead-210 and radon-222, which is sometimes present in natural gas. The amount of radioactivity that accumulates in oil and gas waites depends on a variety of factors, including the amount of uranium and thorium present in the subsurface formation, the formation fluid chemistry, extraction and treatment processes, and the age of the production well.

The source for most oil and gas NORM is dissolved radium that is transported to the surface in the produced water waste stream. Radium dissolution and precipitation depend on the formation water salinity, $\mathrm{pH}$, temperature, and pressure. Dissolved radium either remains in solution in the produced water, or, under proper conditions, coprecipitates with barium, strontium, or calcium to form either hard sulfate scales or more granular silicate and carbonate sludges. Radioactive scale deposits are found in all types of water-handling equipment (e.g., piping, filters, the components of brine disposal/injection wells). Radioactive sludge deposits accumulate inside piping, separators, heater/treaters, storage tanks, and other equipment used to handle produced water. Production and processing equipment may be contaminated by deposits of radioactive scale and sludge. Such contamination can lead to disposal problems when the equipment is taken off-line for repair or replacement.

A number of NORM surveys have characterized the occurrence of NORM. In general, radium concentrations tend to be highest closest to the wellhead and in more saline waters. Because water production usually increases with the age of a well, NORM tends to be more prevalent at older, producing properties. Total radium concentrations in produced water samples range from undetectable levels to $2,800 \mathrm{pCi} / \mathrm{L}$. Radium concentrations in scale samples range from background levels to several thousand picocuries per gram and in sludge samples, from background levels to several hundred picocuries per gram. However, a recent NORM survey conducted in Michigan indicates that NORM concentrations may be much higher than these reported ranges suggest. Extremely high radium concentrations were measured in this survey: in produced water, as high as $29,000 \mathrm{pCi} / \mathrm{L}$; in scale, as high as $159,000 \mathrm{pCi} / \mathrm{g}$; and in sludge, as high as $6,600 \mathrm{pCi} / \mathrm{g}$.

According to the U.S. Environmental Protection Agency, median exposure levels for oil production equipment range from 2 to $42 \mu \mathrm{rem} / \mathrm{h}$ above background and for gas processing equipment, from 2 to $76 \mu \mathrm{rem} / \mathrm{h}$ above background. Most of these readings were taken on equipment assumed to contain deposits of NORM only on inside surfaces; however, the Michigan survey recently detected NORM-contaminatsd scales on the outside surfaces of downhole casing and tubing. Elevated exposure rates as high as 5,300 $\mu \mathrm{R} / \mathrm{h}$ were measured in Michigan and may be attributable to external deposits of NORM.

To date, efforts to characterize the geographic distribution of NORM have been limited by poor statistical representation. The most comprehensive survey indicated that the 
geographic areas of highest equipment exposure levels are the Gulf Coast region from Florida to Texas, northeastern Texas, southeastern Illinois, and southern Kansas. However, the data used in this survey did not fully represent the industry. Many producing regions were not surveyed, and readings wers collected primarily from equipment located in producing fields previously identified as contaminated. In addition, statistically designed sampling schemes were not followed. These data collection limitations restrict the extrapolation of survey results into unsurveyed areas.

The fate of NORM in the environment has not been fully defined, and few human health risk assessments have been conducted. The fate of radium in NORM-contaminated produced water discharged to coastal and offshore waters appears to be affected by daily and seasonal fluctuations in salinity, rainfall, runoff, tides, and sediment dispersal, which make it difficult to predict how specific locations will be affected by NORM discharges. When NORM-contaminated water is discharged to surface soils, dissolved radium is rapidly absorbed by the soil, and radium infiltration rates are very low. Even if radium migrates to a freshwater aquifer, it is not very mobile because freshwater formations can absorb large amounts of radium. Most biota, except marine plankton, reject radium in favor of calcium, and, when metabolized, most radium accumulates in an organism's skeleton or shell.

Humans can be exposed to NORM radiation along many different pathways. Populations at risk from exposure to NORM radiation include workers at equipment cleaning facilities, oil field workers, workers at facilities where NORM is disposed of, and the general public. The pathways of concern for occupational exposure are external gamma exposure, dust inhalation, skin beta exposure, and radon inhalation. External gamma exposure can occur when the radioactivity of NORM inside equipment is high enough that gamma rays penetrate the walls; when NORM-contaminated scale builds up on the outside of casing and tubing strings; and when contaminated scale and sludge are removed from equipment, thereby eliminating the shielding factor provided by the equipment walls. Dust inhalation or skin beta exposure can occur whenever contaminated scale and sludge are uncontained, but the risk is particularly great when equipment cleaning processes release airborne particles of NORM. Risk to workers is increased at disposal facilities where NORMcontaminated wastes and equipment are buried without radiation control features and at smelters where NORM detection systems have not been installed.

The general public risks exposure to NORM via radon inhalation, groundwater ingestion, surface-water ingestion, and food ingestion. Improper disposal of NORM may contaminate soil and water and lead to higher indoor radon levels in nearby buildings. A recent risk assessment for radium discharged in produced waters indicated a potential risk of exposure to an individual who ingests large amounts of seafood harvested near a produced water discharge point over a lifetime.

In the past, NORM-contaminated wastes and equipment were managed without any radiation control guidelines. Currently, most contaminated materials are being stored until disposal guidelines can be developed. A risk assessment of disposal alternatives identified the maximum concentrations of radioactivity that can be handled without exceeding any 
radiation exposure limits. This study concluded that deep, subsurface disposal (i.e., in salt domes, plugged and abandoned wells, formations below freshwater aquifers) provides the greatest degree of isolation. The limiting exposure pathway of concern associated with deep disposal is groundwater ingestion. In contrast, landspreading provides the least amount of isolation and poses the greatest risk of external gamma exposure.

A review of available data shows that the occurrence of NORM (and its associated health risks) may be significant enough to warrant more stringent regulations. However, before these regulations can be developed, additional research is needed to better characterize the occurrence and distribution of NORM throughout the industry and to quantify the hazards posed by NORM to industry workers and the general public. This characterization will help ensure that regulatory programs provide adequate protection without burdening the oil and gas industry unnecessarily. Research and development of waste treatment and minimization technologies are also needed to help lower the risk associated with NORM and to reduce disposal costs.

Although many federal regulations could be amended to provide NORM standards, such amendments do not seem likely in the near future. In the absence of federal guidelines, states have been forced to develop their own regulatory programs. While it may be most appropriate to regulate NORM through state-run programs, many states probably lack adequate resources to support this effort. Federal guidance could help alleviate the strain on state resources without compromising the applicability of the regulations. 


\section{INTRODUCTION}

Radioactive elements occur naturally in the earth's rocks, soils, and water in varying concentrations. Many industrial operations, including oil and gas extraction and processing, tend to accumulate naturally occurring radioactive materials (NORM) at concentrations above normal in by-product waste streams. The presence of elevated NORM concentrations (i.e., above background) in some oil and gas waste streams has been recognized since the early 1930s (Otto 1989); however, NORM concentrations have been largely unregulated. Since the mid-1980s, both federal and state regulatory agencies have become increasingly concerned about the presence of NORM.

NORM concentrations in oil and gas wastes vary considerably, both geographically and with respect to specific waste streams. Concentrations can range from undetectable levels to $40,000 \mathrm{pCi} / \mathrm{g}$ of radium-226 (Ra-226), the primary isotope of concern (U.S. Environmental Protection Agency [EPA] 1991). The EPA (1991) estimates an average total radium concentration in oil and gas NORM of $210 \mathrm{pCi} / \mathrm{g}(155 \mathrm{pCi} / \mathrm{g}$ of Ra-226 and $55 \mathrm{pCi} / \mathrm{g}$ of radium-228 [Ra-228]). Radium is considered to be the most hazardous radionuclide in the natural environment (Brookins 1984), and average radium concentrations in soil ran ge from one-half to several picocuries per gram (American Petroleum Institute [API] 1992). NORM concentrations in some oil and gas wastes are similar to those found in uranium mill tailings, which are heavily regulated by the Atomic Energy Act (AEA). The petroleum industry has stated that most NORM occur in small quantities and at low levels of radioactivity (API 1992); however, highly elevated radionuclide concentrations do occur and warrant attention.

The EPA estimates that oil and gas activities generate approxinately $360,000 \mathrm{~m}^{3}$ of NORM wastes each year; most of this waste currently is being stored until disposal guidelines are developed. On the basis of this estimate of annual generation, the EPA projects that $8.3 \times 10^{6} t$ of NORM wastes will accumulate over the next 20 years (EPA 1991). This large volume indicates that timely development of appropriate NORM management and disposal guidelines and regulations is imperative.

\subsection{ORIGINS OF NORM IN OIL AND GAS WASTES}

The sources for most radioactivity in oil and gas NORM wastes are long-lived isotopes of uranium (primarily uranium-238 [U-238]) and thorium (primarily thorium-232 [Th-232]). These isotopes are present in varying concentrations in the subsurface formations from which oil and gas are produced. Both U-238 and Th-232 are relatively insoluble and remain in place in the subsurface formations; however, some of their decay products are slightly soluble and can become mobilized in the liquid phases of the formation. The principal radionuclide of concern in NORM wastes (Ra-226) results from the decay of U-238. Other radionuclides of concern include Ra-228 (from the decay of Th-232), radon-222 (Rn-222) (a daughter product of Ra-226), and lead-210 ( $\mathrm{Pb}-210)$ (a daughter product of $\mathrm{Rn}-222$ ). The complete decay chains for U-238 and Th-232 are shown in Figures 1 and 2, respectively. 


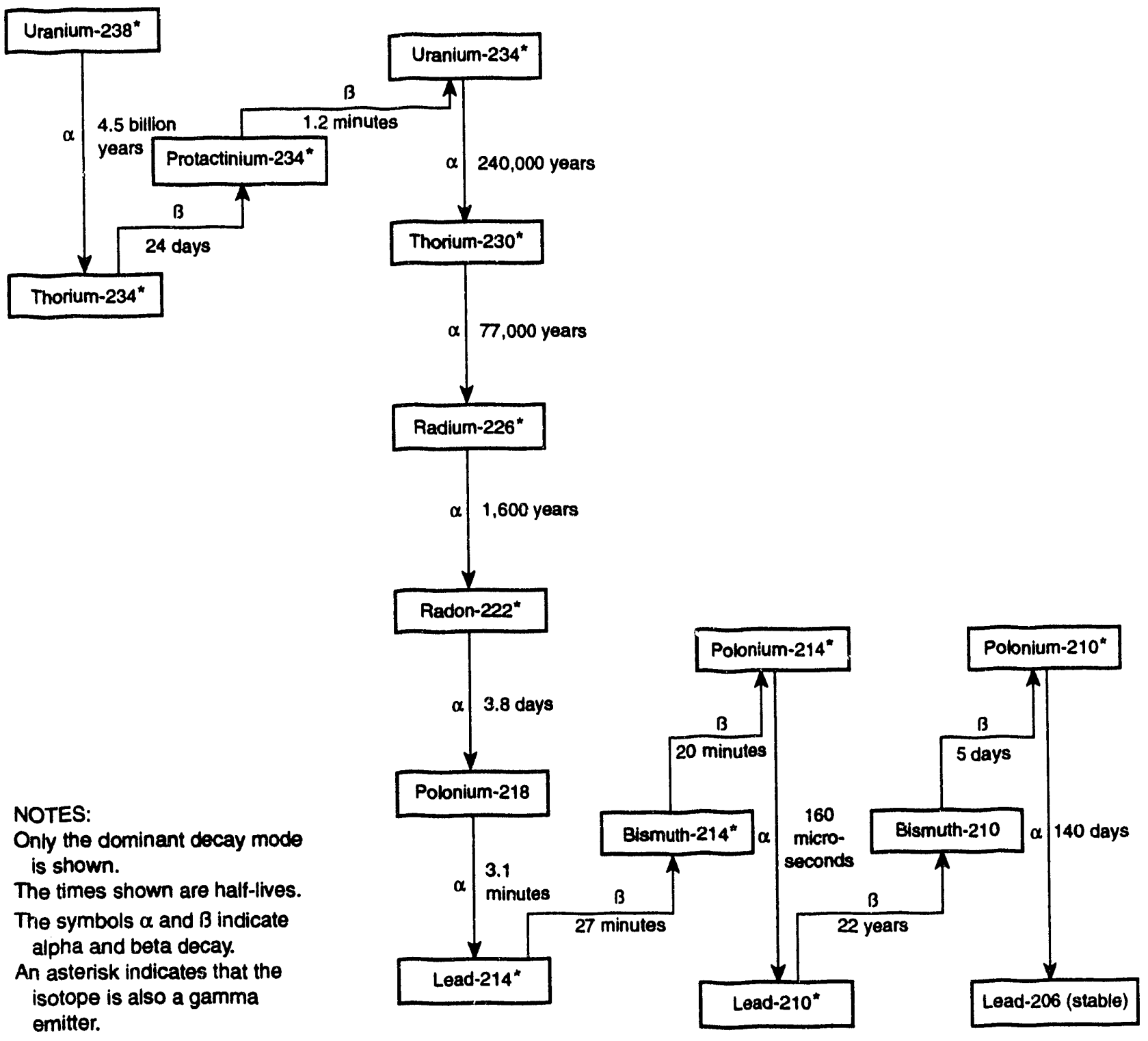

FIGURE 1 Uranium-238 Decay Series

NORM concentrations in oil and gas wastes vary according to the amount of uranium and thorium originally present in the subsurface formations, the mobility of the radium decay products in formation water, and the amount of water produced in conjunction with the hydrocarbons. Radium dissolution and precipitation are complex processes controlled by formation fluid chemistry and by temperature and pressure phase changes.

\subsection{REGULATION OF NORM}

NORM generated in elevated concentrations by most industrial processes are largely unregulated. Most federal regulations do not address management and disposal of NORM, and very few states have develored regulations specific to oil and gas NORM. 


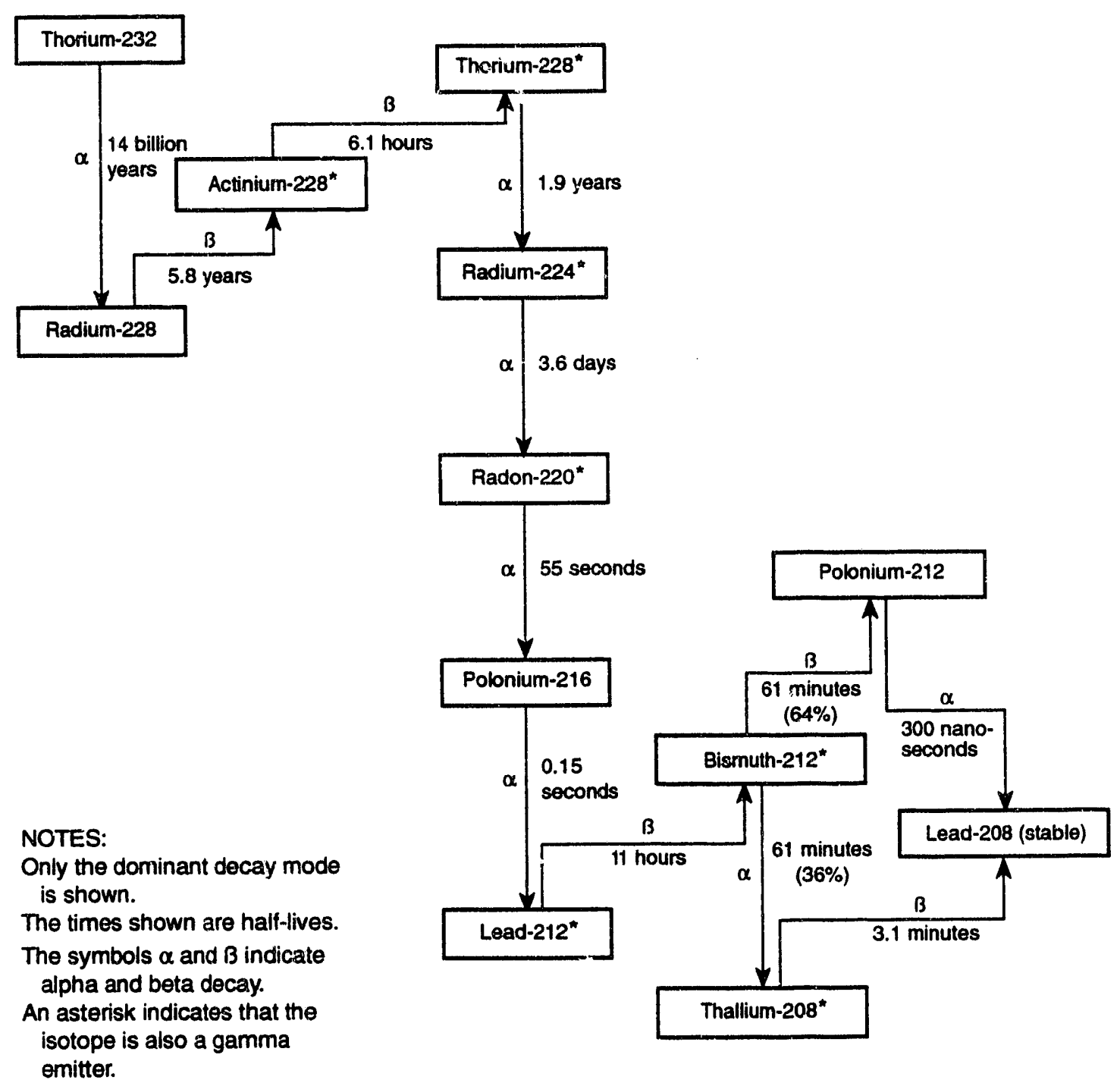

FIGURE 2 Thorium-232 Decay Series

\subsubsection{Federal Regulations}

The Occupational Safety and Health Administration (OSHA) has developed safety regulations to limit worker radiation exposure. The oil and gas industry is required to comply with all OSHA regulations or approved, equivalent state regulations. The OSHA regulations, contained in the Code of Federal Regulations (CFR) (29 CFR 1910.96), require employers to evaluate radiation hazards in the workplace and to limit worker exposure to ionizing radiation. In a 40-h work week, no employee should be exposed to airborne radioactive material in an average concentration of $3 \mu \mathrm{Ci} / \mathrm{mL}$ of $\mathrm{Ra}-226$ and $7 \mu \mathrm{Ci} / \mathrm{mL}$ of Ra-228 (29 CFR 1910.96(c)(1)). General labeling and posting requirements for the use, storage, and transport of radioactive material are also established in 29 CFR 1910.96. 
Neither the EPA nor the U.S. Nuclear Regulatory Commission (NRC) has established federal regulations that directly govern NORM wastes from the oil and gas industry, although a number of environmental legislative acts could be amended to encompass these wastes (Sections 1.2.1.1-1.2.1.8). The NORM Task Group on Regulatory Analysis thoroughly discusses the applicability of federal regulations to oil and gas NORM in an API report (1988).

\subsubsection{Atomic Energy Act}

The AEA regulates the disposition and management of most radioactive wastes generated in the United States. However, the existing AEA definitions of regulated radioactive materials are very specific; they focus on radioactive materials associated with fission reactors and atomic weapons. The AEA does not regulate NORM generated by most other activities, including the oil and gas industry. The AEA could be amended to redefine "by-product materials" to include NORM generated by a variety of industrial processes. Amendments in 1978 included NORM in uranium mill tailings.

\subsubsection{Low-Level Radioactive Waste Policy Act}

The Low-Level Radioactive Waste Policy Act as amended in 1986 provides guidance to the states on the disposal of low-level radioactive waste (LLW) similar to oil and gas NORM. However, as defined by the NRC, LLW does not include oil and gas NORM.

\subsubsection{Resource Conservation and Recovery Act}

Under the Resource Conservation and Recovery Act (RCRA), specific regulations that address NORM have not been promulgated, and NORM is not considered a listed or characteristic waste. Most waste streams generated by oil and gas exploration and production (E\&P) activities that could contain NORM in elevated concentrations are exempt from regulation as hazardous wastes under RCRA by virtue of the 1980 Bevill Amendment. Under this exemption, wastes containing NORM are regulated in accordance with Subtitle D provisions for nonhazardous solid waste. Some refinery wastes that contain NORM may be regulated as characteristic hazardous wastes; however, this hazardous classification is determined by waste stream constituents other than NORM.

\subsubsection{Comprehensive Environmental Response, Compensation, and Liability Act}

Radionuclides are listed as a hazardous substance under the Comprehensive Environmental Response, Compensation, and Liability Act (CERCLA) because they are hazardous air pollutants under the Clean Air Act (CAA). Because they are exempt from RCRA Subtitle C, oil and gas waste streams that may contain NORM are not regulated as hazardous substances under CERCLA, although the NORM themselves may be. Under 
40 CFR 302.4, the reportable quantity for total radionuclides is $1 \mathrm{lb}$ or, for individual radionuclides, specified concentrations (expressed in curies), whichever is less. For Ra-226, $\mathrm{Ra}-228$, and $\mathrm{Rn}-222$, the reportable quantity is $0.1 \mathrm{Ci}$. The $1-\mathrm{lb}$ limit refers to $1 \mathrm{lb}$ of radionuclides, not $1 \mathrm{lb}$ of NORM-contaminated waste. However, the concentration limits refer to the radionuclide concentration of the entire released product.

\subsubsection{Superfund Amendments and Reauthorization Act - Title III}

None of the constituents of NORM (i.e., radium, radon, barium, sulfate, or ionizing radiation) are listed as "extremely hazardous substances" that require emergency notification and emergency response plenning under Title III of the Superfund Amendments and Reauthorization Act.

\subsubsection{Clean Air Act}

As required by the CAA, the EPA has developed National Emissions Standards for Hazardous Air Pollutants (NESHAPs) specific to radion'uclide emissions from a number of sources. However, none of the existing NESHAPs, which were developed for specific industrial activities, include NORM generated by the oil and gas industry.

\subsubsection{Clean Water Act}

Although the Clean Water Act (CWA) gives the EPA authority to regulate the discharge of radioactive materials to surface waters through the National Pollutant Discharge Elimination System (NPDES) permitting scheme, specific effluent limits have not been established for low-level NORM discharges. The EPA has added oil and gas extraction points to the list of pollutant sources subject to regulation under the CWA but has not promulgated regulations.

\subsubsection{Safe Drinking Water Act}

Under the provisions of the Safe Drinking Water Act (SDWA), the EPA has issued a drinking water standard of $5 \mathrm{pCi} / \mathrm{L}$ for Ra-226 and Ra-228 combined. In 1991, the EPA published a proposed rulemaking that would raise the radium standard to $20 \mathrm{pCi} / \mathrm{L}$ and establish a drinking water standard of $300 \mathrm{pCi} / \mathrm{L}$ for radon. ${ }^{1}$ To date, no final regulations have been issued.

These standards provide for the protection of underground sources of drinking water (USDWs) and effectively prohibit the disposal of NORM by methods that could jeopardize drinking water quality. Underground injection of oil and gas wastes is regulated by the

1 Federal Register, Vol. 56, No. 138, p. 33050, July 18, 1991. 
Underground Injection Control (UIC) Program to protect USDWs from other waste stream constituents. As a result, NORM-contaminated wastes injected underground in UICcontrolled wells should not be able to migrate to USDWs.

\subsubsection{Congressional Activity}

Congressional activity that addresses the NORM issue has been limited, but awareness appears to be increasing. In April 1992, Rep. Eckart (D-Ohio) introduced H.R. 4905, the Oil and Natural Gas Exploration and Production Waste Management Improvement Act. This proposed bill would amend the Solid Waste Disposal Act to regulate the disposal of E\&P wastes currently exempt from RCRA Subtitle C regulations. H.R. 4905 specifically addresses oil and gas NORM and would require the EPA to develop NORM regulations to establish notification and reporting requirements; survey requirements; limitations on the release of contaminated equipment and property; worker protection standards; and NORM treatment, storage, and disposal standards.

In addition, the NORM issue was raised in April 1992 at a congressional hearing before the Senate Committee on Governmental Affairs on radiological contamination in the United States. The potential for widespread radiological contamination at oil and gas facilities was discussed, and increased regulation was suggested.

\subsubsection{State Regulations}

A number of states have begun to develop regulatory programs for oil and gas NORM. The Conference of Radiation Control Program Directors (CRCPD), an organization of the directors of state regulatory agencies, has drafted a set of model regulations for NORM management, referred to as Part N (CRCPD 1990). The proposed regulatory model, currently awaiting adoption by the whole conference, establishes radiation protection standards for the possession, use, transfer, and disposal of NORM. Specifically, Part N provides guidelines for the development of licensing programs, conditions for regulatory exemption, worker protection standards, and release limits for radioactive material effluent. Louisiana and Texas have used these guidelines to develop state regulatory programs; other states are expected to follow their lead.

Louisiana is the first state to have developed and implemented a NORM regulatory program (Louisiana Department of Environmental Quality 1992). Under this program, operators who could handle or possess NORM are required to survey their property. An operator who handles materials with NORM concentrations greater than $5 \mathrm{pCi} / \mathrm{g}$ above background of 226-Ra or 228-Ra, or equipment with readings greater than $25 \mu R / h$ above background, must obtain a general license from the state. General licensees are subject to worker protection and NORM management standards. A written waste management plan is required to store NORM waste for more than 90 days. All NORM waste must be disposed

of at a licensed NORM disposal facility, and disposal records, including shipping manifests, must be maintained. Land cannot be released for unrestricted use if soil contamination levels 
are greater than $5 \mathrm{pCi} / \mathrm{g}$ above background in the top $15 \mathrm{~cm}$ of soil, and $15 \mathrm{pCi} / \mathrm{g}$ above background in any lower soil horizons, averaged over a $100-\mathrm{m}^{2}$ area, in areas where the radon emanation rate is greater than $20 \mathrm{pCi} / \mathrm{m}^{2} / \mathrm{s}$.

Texas has developed a set of proposed NORM regulations that draw heavily on the Part N model regulations (Texas Department of Health 1992). Under these proposed regulations, manufacturers of NORM, distributors of products containing NORM, and persons providing decontamination of NORM-contaminated equipment and facilities will be required to have a special license. Contaminated equipment with external readings greater than $50 \mu \mathrm{R} / \mathrm{h}$ will not be suitable for release. Maximum soil contamination levels will be established at $3 \Gamma \mathrm{pCi} / \mathrm{g}$, averaged over a maximum depth of $15 \mathrm{~cm}$ of soil.

The Michigan Department of Public Health (1992) has developed draft interim standards for the control of oil and gas NORM. These standards are considered advisory and are intended to apply to any facility involved with oil and gas production; receipt, storage, or recycling of used production equipment; or processing and disposal of NORM-contaminated wastes. Under these standards, NORM containing less than $5 \mathrm{pCi} / \mathrm{g}$ of Ra-226 are exempt from requirements for radiological protection. As in Louisiana, soil contamination levels are established at $5 \mathrm{pCi} / \mathrm{g}$ above background in the top $15 \mathrm{~cm}$ of soil, and $15 \mathrm{pCi} / \mathrm{g}$ above background in any lower soil horizons, averaged over a $100-\mathrm{m}^{2}$ area. NORM disposal standards state that nonexempt NORM should be disposed of at LLW disposal facilities; at a licensed NORM disposal facility; by underground injection; or, if the average Ra-226 concentration is not greater than $50 \mathrm{pCi} / \mathrm{g}$, at a Michigan Type II landfill. 


\section{ACCUMULATION OF NORM IN OIL AND GAS WASTES}

Most radioactivity in NORM wastes is derived from the decay of U-238 and Th-232, which are present in varying concentrations in subsurface formations from which oil and gas are produced. In general, U-238 and Th-232 concentrations tend to be highest in clay-rich formations (e.g., shales, granites, some sandstones), although some uranium and thorium may be present in limestones and evaporites. Another source of radioactivity in NORM waste is the uranium present in carbonaceous materials such as bitumen, pyrobitumen, and gilsonite (Michigan Department of Natural Resources and Michigan Department of Public Health 1991). Both U-238 and Th-232 are relatively insoluble and remain in place in subsurface formations. However, their radium decay products (Ra-226 and Ra-228) are slightly soluble and can become mobilized in the liquid phases of the formation. Other radionuclides of concern include $\mathrm{Rn}-222$ and $\mathrm{Pb}-210$.

NORM accumulates in elevated concentrations in oil and gas waste streams primarily when radium isotopes are dissolved from the subsurface formation and carried to the surface in the produced water. The oil and gas waste streams most likely to be contaminated by elevated NORM concentrations include produced water, scale, and sludge. Production and processing equipment may contain residual quantities of these wastes, which can cause disposal problems when equipment is taken off-line. Minor amounts of radionuclides also may be transported as (1) dissolved radium or radon in the produced hydrocarbons or (2) uranium, thorium, and radium nuclides in the drill cuttings and drilling fluid. Currently available evidence suggests that these secondary transport mechanisms do not result in widespread occurrences of elevated NORM contamination.

The amount of radioactivity that accumulates in any of the oil and gas wastes depends on the amount of radionuclides present in the subsurface formation, formation fluid chemistry, extraction processes, treatment processes, and age of production. Formation fluid chemistry determines whether radium dissolution and precipitation will occur. In general, radium solubility increases in water that has (1) a high saline content and (2) either low or high $\mathrm{pH}$ values. Radium precipitation rates increase with decreasing temperature and pressure conditions such as those encountered when subsurface fluids are brought to the surface. Extraction processes (e.g., waterfloods, steam floods, chemical floods) and treatment processes can alter formation fluid chemistry or effect temperature and pressure changes that increase or decrease radium mobility. Because most radium is brought to the surface by

produced water, a higher water production rate, which is characteristic of older fields, can result in increased NORM concentrations.

NORM radioactivity levels in produced water, scale, and sludge usually are characterized in terms of radium activity level, that is, the number of radioactive atoms that disintegrate and emit radiation in a given unit of time. Activity levels (or concentrations) usually are expressed in terms of picocuries per gram of solid material or picocuries per liter of water or air ( $1 \mathrm{Ci}=2.2$ trillion disintegrations per minute). Total radium concentration can be measured, or Ra-226 and Ra-228 can be measured separately. Because the activity 
level of Ra-226 usually is three times that of Ra-228, Ra-226 is the primary isotope of concern with respect to long-term radiological concerns in waste disposal (EPA 1991). However, total radium concentrations often are discussed because simple field measurements cannot distinguish between the two isotopes.

NORM radioactivity levels in production and processing equipment typically are characterized in terms of the number of gamma-ray emissions in a given unit of time. External readings usually are taken with a calibrated scintillation detector and measured in counts per minute, microroentgens per hour, or microrems per hour. Gamma-ray emissions are related to activity levels; however, correlating the two is difficult because (1) some of the gamma rays may be absorbed by the metal walls of the equipment or by the scale, and (2) NORM distribution within the equipment may vary (API 1992).

\subsection{PRODUCED WATER}

The source for most oil and gas NORM is dissolved radium radionuclides transported to the surface in the produced water waste stream. Radium concentrations in produced water vary from undetectable levels to $2,800 \mathrm{pCi} / \mathrm{L}$ (Snavely 1989). A recent study of oil-field produced water discharged to the Gulf of Mexico offshore Louisiana determined average total radium concentrations of $539 \mathrm{pCi} / \mathrm{L}(262.3 \mathrm{pCi} / \mathrm{L}$ of $\mathrm{Ra}-226$ and $276.7 \mathrm{pCi} / \mathrm{L}$ of $\mathrm{Ra}-228)$ (Brookhaven National Laboratory [BNL] 1992). Although only a limited number of samples were collected, brine produced at oil and gas facilities in Michigan measured as high as $29,000 \mathrm{pCi} / \mathrm{L}$ of Ra-226 (Minnaar 1992). The NRC's limit for total radium content in liquid wastes discharged to areas of unrestricted access is $30 \mathrm{pCi} / \mathrm{L}$ (Snavely 1989). The current drinking water standard under the SDWA is $5 \mathrm{pCi} / \mathrm{L}$.

Radium concentrations tend to be higher in more saline waters, although high salinity does not always indicate the presence of radium. Salinity of produced water ranges from approximately $5,000 \mathrm{mg} / \mathrm{L}$ to more than $300,000 \mathrm{mg} / \mathrm{L}$ of total dissolved solids (TDS).

Soluble radium may precipitate or remain in solution depending on water salinity and on temperature and pressure phase changes. If conditions are conducive to precipitation (decreasing temperature and pressure), radium usually coprecipitates with other alkaline earth elements (e.g., barium, strontium, calcium) to form sulfates, carbonates, and silicates inside production or processing equipment. Radium that remains in solution is disposed of with the produced water. Approximately $91 \%$ of produced water is injected underground into either enhanced oil recovery (EOR) wells or disposal wells; the remaining $9 \%$ is disposed of via surface discharge.

\subsection{SCALE}

The highest concentrations of radium typically are found in scale deposits that form when dissolved radium coprecipitates with barium, strontium, or calcium sulfates. These sulfates form hard, insoluble deposits on the inside of piping, filters, brine disposal/injection 
wells, and other water handling equipment. In Michigan, radioactive scale deposits also have been detected on exterior surfaces of downhole casing and tubing (Minnaar 1992). Scale deposits can thicken and may need to be removed by cleaning processes to ensure that equipment will operate.

In general, radium concentrations are highest in wellhead piping and in production piping near the wellhead (EPA 1991). Radium content in most scale ranges from background levels to several thousand picocuries per gram (Baird et al. 1990). However, much higher concentrations have been measured in Michigan (i.e., from 76,000 to $159,000 \mathrm{pCi} / \mathrm{g}$ of Ra-226 [Minnaar 1992]), suggesting that the range of NORM concentration is much greater.

Radon emanation rates (the fraction of radon released) from scale typically are around 5\% (Nielson et al. 1988), primarily because the hard, solid structure of the scale inhibits the release of radon as gaseous progeny.

\subsection{SLUDGE}

Sludge deposits consist of accumulations of heavy hydrocarbons, tight emulsions, produced formation sand, and minor amounts of corrosion and scaly debris that settle out of suspension in some oilfield equipment. Radium concentrations in sludge generally are much lower than concentrations in pipe scale. NORM in sludge accumulate when radium coprecipitates with silicates and carbonates inside piping, separators, heater/treaters, storage tanks, and any other equipment where produced water is handled. Typically, NORMcontaminated sludge is characterized by trace radium concentrations that range from background to $300 \mathrm{pCi} / \mathrm{g}$ (Baird et al. 1990), although the Michigan measurements included one sludge sample with $6,600 \mathrm{pCi} / \mathrm{g}$ (Minnaar 1992).

Because of its more granular nature, radon emanation rates from sludge are higher, around 22\%, than emanation rates from insoluble scale (Nielson et al. 1988).

\subsection{PRODUCTION AND PROCESSING EQUIPMENT}

NORM-contaminated sludge and scale accumulate inside oil production and processing equipment. NORM contamination tends to be greatest in equipment where produced water is handled or stored, such as water lines, flow lines, injection wellheads, vapor recovery units, water storage tanks, heater/treaters, and separators (Table 1). When contaminated equipment is taken off-line, the NORM present inside can cause disposal problems. Some types of equipment (e.g., flow lines, storage tanks) can be cleaned to remove the contaminated sludge and scale. Cleaned equipment may be reused if it is in good condition; however, the cleaning process generates radioactive wastes that require disposal. Other types of equipment (e.g., wellhead filters, pumps) cannot be cleaned easily and must be disposed of intact. 
TABLE 1 Radiation Exposure Levels Associated with NORM in Oil and Gas Production and Processing Equipment

\begin{tabular}{|c|c|c|c|c|}
\hline \multirow[b]{2}{*}{ Equipment $^{\mathrm{a}}$} & \multirow{2}{*}{$\begin{array}{c}\text { Percentage of } \\
\text { Observations } \\
\text { above } \\
\text { Background }^{b}\end{array}$} & \multicolumn{3}{|c|}{$\begin{array}{c}\text { Difference above } \\
\text { Background }(\mu \mathrm{rem} / \mathrm{h})^{\mathrm{b}}\end{array}$} \\
\hline & & Minimum & Median & Maximum \\
\hline \multicolumn{5}{|c|}{ Oil Production Facilities } \\
\hline $\begin{array}{l}\text { WOTHER } \\
\text { WPROD } \\
\text { METER } \\
\text { PUMP } \\
\text { OTHER } \\
\text { STANK } \\
\text { MANIFOLD } \\
\text { SUMP } \\
\text { SEP } \\
\text { H/T } \\
\text { WTANK } \\
\text { VRU } \\
\text { WINJ } \\
\text { WLINE } \\
\text { FLINE }\end{array}$ & $\begin{array}{l}21 \\
33 \\
24 \\
30 \\
42 \\
38 \\
35 \\
56 \\
48 \\
50 \\
62 \\
22 \\
49 \\
52 \\
24\end{array}$ & $\begin{array}{l}1.2 \\
0.1 \\
1.0 \\
0.1 \\
0.1 \\
0.1 \\
0.1 \\
0.1 \\
0.1 \\
0.1 \\
0.1 \\
0.2 \\
1.0 \\
0.2 \\
0.1\end{array}$ & $\begin{array}{r}2.0 \\
2.3 \\
3.0 \\
3.0 \\
4.0 \\
4.0 \\
6.0 \\
7.0 \\
7.8 \\
8.0 \\
8.0 \\
17.0 \\
20.0 \\
34.6 \\
42.0\end{array}$ & $\begin{array}{r}5.5 \\
1,487.0 \\
92.0 \\
986.0 \\
3,785.0 \\
2,475.0 \\
2,995.0 \\
793.0 \\
4,491.0 \\
3,490.0 \\
3,786.0 \\
1,287.0 \\
886.0 \\
2,790.0 \\
2,991.0\end{array}$ \\
\hline \multicolumn{5}{|c|}{ Gas Producing Facilities } \\
\hline $\begin{array}{l}\text { COMPRESSOR } \\
\text { DEHYDRATOR } \\
\text { SWEETENER } \\
\text { INLET SCRUB } \\
\text { METER } \\
\text { CRYO UNIT } \\
\text { OTANK } \\
\text { OTHER } \\
\text { FRAC TOWER } \\
\text { REFRIGER } \\
\text { BOTTOMS PUMP } \\
\text { PTANK } \\
\text { OPUMP } \\
\text { PPUMP } \\
\text { PROD LINE } \\
\text { PUMP } \\
\text { REFLUX PUMP }\end{array}$ & $\begin{array}{l}18 \\
30 \\
13 \\
26 \\
32 \\
40 \\
33 \\
38 \\
45 \\
39 \\
75 \\
73 \\
49 \\
75 \\
56 \\
67 \\
86\end{array}$ & $\begin{array}{l}0.3 \\
0.3 \\
0.2 \\
0.1 \\
0.3 \\
1.0 \\
0.2 \\
0.3 \\
0.2 \\
0.1 \\
0.5 \\
0.5 \\
0.4 \\
0.1 \\
0.1 \\
3.0 \\
0.2\end{array}$ & $\begin{array}{l}2.0 \\
3.0 \\
3.45 \\
5.0 \\
5.5 \\
6.0 \\
6.0 \\
7.0 \\
9.5 \\
16.0 \\
17.0 \\
25.0 \\
27.75 \\
31.0 \\
35.0 \\
38.0 \\
76.0\end{array}$ & $\begin{array}{r}490.0 \\
529.0 \\
220.5 \\
701.0 \\
695.0 \\
2,985.0 \\
383.0 \\
995.0 \\
395.0 \\
595.0 \\
220.0 \\
680.0 \\
1,391.0 \\
1,041.0 \\
1,080.0 \\
73.0 \\
2,985.0\end{array}$ \\
\hline
\end{tabular}

a Equipment abbreviations are defined in Table 2.

b Median background of $7.0 \mu \mathrm{rem} / \mathrm{h}$.

Source: Otto (1989). 
TABLE 2 Abbreviations Used in Table 1 to Designate Types of Oil and Gas Production and Processing Equipment

Abbreviation - Description

Oil Production Equipment

$\begin{array}{ll}\text { FLINE } & \text { Flow lines, including all valves and elbows } \\ \text { H/T } & \text { Heater/treater } \\ \text { MANIFOLD } & \text { Manifold/header piping, valves, chokes, etc. } \\ \text { METER } & \text { All metering equipment, including meters, meter runs, and } \\ & \text { strainers } \\ \text { OTHER } & \text { All other measurements on service equipment } \\ \text { PUMP } & \text { All pumps } \\ \text { SEP } & \text { All separators } \\ \text { STANK } & \text { Stock tanks } \\ \text { SUMP } & \text { Sumps, including pits, pigtraps, and ponds } \\ \text { VRU } & \text { Vapor recovery units } \\ \text { WINJ } & \text { Injection wellhead } \\ \text { WLINE } & \text { Water lines, including all valves and elbows } \\ \text { WOTHER } & \text { Other wellheads, except injection and production wellheads } \\ \text { WPROD } & \text { Production wellhead } \\ \text { WTANK } & \text { Water tanks }\end{array}$

Gas Processing Equipment

BOTTOMS PUMP

COMPRESSOR

CRYO UNIT

DEHYDRATOR

FRAC TOWER

INLET SCRUB

METER

OPUMP

OTANK

OTHER

PPUMP

PROD LINE

PTANK

REFLUX PUMP

REFRIGER

SWEETENER
Pumps transferring liquids from the bottoms of towers

Compressors and associated equipment

All cryogenic process equipment

Dehydration equipment

All process towers and columns

Inlet scrubbers, separators, etc.

All metering equipment, including meters, meter runs, and strainers

All other pumps

All other tanks

All other gas processing equipment

Propane pump

All product lines

Propane tank

All reflux pumps

All propane refrigeration system equipment

All gas sweetening equipment

Source: Otto (1989). 
Natural gas production and processing equipment may be contaminated with a thin film of $\mathrm{Pb}-210$ plated onto interior surfaces. Lead-210 is a long-lived daughter product of $\mathrm{Rn}-222$, which sometimes is produced along with natural gas and partitioned mainly between the propane and ethane fractions. If allowed to accumulate for a sufficient time, $\mathrm{Pb}-210$ will decay to produce bismuth-210 and polonium-210, relatively short-lived isotopes that decay to stable lead-206. Gas plant equipment with the highest levels of $\mathrm{Pb}-210$ includes reflux pumps, propane pumps and tanks, other pumps, and production lines (Table 1). Lead-210 decays by beta emission, emitting only low-energy gamma rays, and poses less disposal hazard and reduced exposure threat to humans than other forms of radiation (Baird et al. 1990). However, because it is difficult to measure radiation levels inside equipment and because worker awareness is low, $\mathrm{Pb}-210$ plating still may pose a significant operational hazard.

Median exposure levels for oil production equipment range from 2 to $42 \mu \mathrm{rem} / \mathrm{h}$ above background; median exposure levels for gas processing equipment range from 2 to $76 \mu \mathrm{rem} / \mathrm{h}$ above background (median background level $=7 \mu \mathrm{rem} / \mathrm{h}$ ) (EPA 1991). According to API, gamma-ray measurements on NORM-contaminated equipment usually indicate levels of radiation below levels considered to be of concern, although survey results from Michigan included exposure rates as high as 5,300 $\mu \mathrm{R} / \mathrm{h}$ (Minnaar 1992). Despite Michigan's elevated readings, the primary threat associated with contaminated equipment is ingestion or inhalation of NORM when the equipment is opened for inspection or repair. It is difficult to predict the activity level of the NORM from external measurements because some radiation is absorbed by the metal wall and distribution of the NORM may vary (API 1992). 


\section{GEOGRAPHIC DISTRIBUTION OF NORM}

To date, efforts to characterize the geographic distribution of NORM-contaminated oil and gas wastes have been limited by poor statistical representation. The most comprehensive industrywide survey, conducted by API, was intended to identify (1) geographic areas of oil production and gas processing facilities that have the greatest occurrence of NORM contamination and (2) the types of equipment at these facilities that have the highest NORM activity levels (Otto 1989). In this survey, more than 36,000 external gamma-ray measurements were collected to evaluate NORM accumulations at oil and gas facilities in 20 states and two offshore ereas. NORM activity levels varied greatly, both geographically and with respect to equipment. The geographic areas with the highest gamma measurements were the Gulf Coast region from Florida to Texas (the overall highest readings were from the Mississippi coast to the Florida panhandle), northeastern Texas, southeastern Illinois, and a few counties in southern Kansas.

Although most of the major oil and gas producing states were represented in the API survey, the representation was disproportionate. In some states, most of the data were collected in only one or two counties, leaving many counties with oil and gas production unrepresented. Most of the readings were taken at facilities that were known or expected to show some degree of radioactivity on the basis of previous survey results, and the number and location of readings taken did not follow statistically designed sampling schemes. These data collection limitations restrict the extrapolation of survey results into unsurveyed areas. The API data may indicate geographic areas where the probability of finding NORM contamination in oil and gas production and processing equipment is high; however, these data cannot be used to indicate absence of NORM contamination in other areas. In addition, recent data from Michigan include NORM concentration values significantly higher than those measured in other studies (Minnaar 1992). These findings indicate that the API data may not identify the geographic areas with the highest readings.

Michigan surveys have measured gamma-ray emissions from the exterior surfaces of oil and brine tanks, vessels, and tubing, as well as from areas of ground potentially contaminated by NORM. The results indicated that approximately $20 \%$ of the leases had equipment with external gamma readings above background (White 1992), but no clear pattern emerged to correlate high readings with specific subsurface formations. 


\section{NORM MANAGEMENT AND DISPOSAL OPTIONS}

In the past, before the hazards of NORM contamination were fully recognized, no disposal guidelines existed. The methods used to dispose of most NORM-contaminated oil and gas wastes usually were determined on the basis of other waste stream constituents. To date, federal guidelines are still nonexistent, and only a few states have begun to establish NORM regulatory programs. As a result, most NORM-contaminated wastes are either disposed of by the methods described in this section or stored until new disposal guidelines can be developed.

\subsection{PRODUCED WATER}

In onshore operations, the primary disposal method for produced water is underground injection into either EOR wells or disposal wells. This disposal method, which accounts for $91 \%$ of the total waste stream, is regulated by the UIC Program to protect USDWs from contamination. Before UIC regulation, which began in the late 1970s, NORMcontaminated produced water was probably injected or migrated into USDWs. The current UIC programs, administered by the EPA and state primacy programs, include approximately 166,453 oil and gas industry injection wells in 31 states (Engineering Enterprises, Inc. 1989). The remaining $9 \%$ of the onshore industry's produced water is disposed of via surface discharge, which is regulated by the NPDES permitting scheme.

In coastal and offshore operations, most produced water is discharged to surrounding surface waters. Most produced water discharged to surface water or the ground is treated to remove hydrocarbons; however, these treatment processes probably do not affect radionuclide contents.

\subsection{SCALE AND SLUDGE}

Scale and sludge deposits, some of which are contaminated with elevated levels of NORM, are disposed of by a number of methods. Most scale is recovered from piping and other equipment when the equipment is sent to a commercial facility for cleaning; some scale is removed at the well site during workover operations. At equipment cleaning facilities, scale may be removed by reaming; high-pressure water blasting; or a process called "rattling," where a high-speed rotating device is inserted into the pipe to break up and loosen the scale. The dry reaming and rattling processes create a fine dust that can increase worker radiation exposure if not properly controlled. Wet reaming processes and water blasting reduce dust but produce large wastewater streams that require treatment. In the past, recovered scale was disposed of by burial and landspreading; as a result, the soil in most equipment cleaning yards and around some well sites may be heavily contaminated with pipe scale. The current trend among equipment decontamination companies is to return recovered NORMcontaminated material to the generator for disposal. 
Sludge deposits are removed from equipment by manual cleaning, washing and pumping, and vacuuming. According to a 1985 API survey, most sludges are disposed of at off-site, commercial facilities (ERT 1988). Although sludges contain a variety of hazardous constituents (e.g., benzene, heavy metals, hydrucarbons), they are regulated as nonhazardous wastes under RCRA; therefore, these off-site facilities, not identified in API's survey, probably are solid waste landfills. As an alternative to disposal, sludges that contain large quantities of hydrocarbons can be disposed of via roadspreading if they are not ignitable and have density values and metal contents consistent with approved road mixes. In some states, sludges may be disposed of via landspreading if their salt and hydrocarbon contents are low enough. Some oily sludges may require treatment by incineration, bioremediation, or chemical and physical processes to remove hydrocarbons before disposal; however, it is unknown how these treatments affect NORM concentrations.

\subsection{PRODUCTION AND PROCESSING EQUIPMENT}

NORM-contaminated production and processing equipment has been disposed of in a number of uncontrolled ways, including smelting, burial, and release for inappropriate reuse. Many scrap metal recycling facilities have installed NORM detection systems in recent years; previously, most NORM went undetected. In some cases, old piping has been reused in fencing, cattle guards, buildings, and playgrounds. Elevated readings have been detected on the exterior surfaces of piping that was recycled as playground equipment. States have begun to restrict inappropriate reuse of contaminated piping; in Louisiana, pipe ends must be welded shut to contain the scale (Raloff 1991).

As an alternative to disposal, it may be more cost-effective to decontaminate some equipment for reuse. Equipment cleaning procedures to remove scale and sludge include manual cleaning, washing and pumping, vacuuming, rattling, high-pressure water blasting, and reaming. Lead-210 films inside gas processing equipment can be removed by chemical cleaning agents or may require physical grinding. All cleaning procedures produce some contaminated waste (e.g., scale, sludge, wastewater, solvents) that requires disposal. To limit worker exposure, the industry has adopted new health and safety procedures such as the use of respirators and masks during cleaning operations. In Louisiana, contaminated waste removed from equipment must be returned to the generator for disposal. Mississippi prohibits removal of NORM-contaminated scale from piping (Raloff 1991).

\subsection{API RECOMMENDATIONS FOR DISPOSAL OF NORM}

In the absence of regulatory guidelines, API has published suggested guidance for the management of NORM generated by oil and gas production activities (API 1992). API provides some specific direction for several disposal alternatives:

- Abandonment in plugged and abandoned wells. Contaminated scale, sludge, and soil can be mixed with cement slurries, if no hydrocarbons are present, and injected into formations or used to plug casing below 
the lowest USDW. Alternatively, these wastes can be mixed with well control fluids and injected intc the same formations before abandonment. NORM-contaminated tubulars can be abandoned in place below the lowest USDW, with or without a cement column.

- Well injection and hydraulic fracturing. Slurries of contaminated scale and sludge can be injected or fractured into formations that are isolated geologically and mechan cally from the lowest USDW. Injection of the contaminated waste should be followed by injection of uncontaminated fluid to fully displace all NORM wastes into the formation.

- Disposal at a licensed NORM waste disposal site. A licensed NORM waste disposal site must meet the EPA's regulations for uranium mill tailings disposal sites specified in $40 \mathrm{CFR} 192$. These regulations require that the site must be designed to be effective for 1,000 years to the extent reasonably achievable, or, in any event, for at least 200 years. It must be designed to limit radon flux to the atmosphere to $20 \mathrm{pCi} / \mathrm{m}^{2} / \mathrm{s}$, averaged over the disposal site and over any 1-yr period. The impoundment usually is designed with an earthen cover for radon control and suitable liners and siting criteria to protect local groundwater from contaminant leaching and migration. After closure, the site is deeded to the state for permanent monitoring and restricted future use. Currently, only one permitted NORM waste disposal facility is operating, although other facilities may be seeking regulatory approval.

- Equipment release to a smelter. Smelting may be a viable option for NORM-contaminated "quipment, although approval must be obtained from regulatory ager ies.

- Landspreading and burial. Landspreading and burial may be suitable options for NORM-contaminated scale, sludge, and equipment; however, regulatory agencies have not yet approved these disposal methods.

\subsection{TREATMENT AND MINIMIZATION OF NORM-CONTAMINATED WASTES}

NORM-contaminated sludge and scale can be treated before disposal by solidification or chemical stabilization to reduce the mobility of radionuclides. Other treatment processes can be used to transfer some of the radionuclides to a more concentrated stream, to minimize the volume of NORM-contaminated wastes, or to prevent NORM accumulations. These processes may drastically reduce the cost associated with NORM management, although further research into their applicability and effectiveness is needed. 


\subsubsection{Scale Inhibition}

A successful scale inhibition program can help keep NORM in solution in the produced water stream. Although scale inhibition may increase the radioactivity of the produced water stream, it reduces the volume of NORM-contaminated scale that must be handled. One benefit associated with this reduction is potentially reduced worker radiation exposure because worker exposure to produced water can be more easily controlled than worker exposure to scale. In addition, most produced water is disposed of via underground injection regardless of its radionuclide concentration. Deep, subsurface disposal provides a high degree of radiation isolation if UIC Program requirements are observed.

Scale formation is a multistep process that depends on a number of variables; control of these variables can reduce precipitation rates (API 1992). Mixing incompatible waters (e.g., injection of incompatible water into an EOR well) can increase precipitation of sulfates and carbonates, including $\mathrm{RaSO}_{4}$. To the extent possible, water chemistry should be monitored to avoid incompatible mixing. In some situations, mixing incompatible waters is necessary; in these instances, the mixtures should be retained to allow precipitates to form and settle and then be filtered. Scale formation often is higher in mechanical components downstream of points where excessive pressure drop and turbulence occur. Modification of production processes to reduce pressure drops and turbulence may reduce scale formation. Precipitated scale crystals adhere to small particles or rough surfaces. Reducing the amount of internal equipment corrosion and limiting the presence of fine material inside the equipment may control the accumulation of scale crystals to some extent.

Chemical scale inhibitors also can be used to interfere with the formation or growth of scale crystals (API 1992). Common scale inhibitors include phosphonates, polycarboxylates, and phosphate esters. These compounds generally are added at low concentrations that range from 1 to 50 parts per million, and their effectiveness is influenced by varying temperatures and water chemistry. For example, polycarboxylaties are effective up to $450^{\circ} \mathrm{F}$, whereas phosphonates are stable up to $250-300^{\circ} \mathrm{F}$ and phosphate esters are useful only at temperatures below $212^{\circ} \mathrm{F}$. Inhibitor performance is consistent in neutral $\mathrm{pH}$ conditions, but variable at either lower or higher $\mathrm{pH}$ values. Highly saline conditions can result in precipitation of inhibitors, thereby limiting their effectiveness.

\subsubsection{Ion-Exchange Treatment}

Ion-exchange treatments often are used to control water chemistry. Argonne National Laboratory recently developed a new ion-exchange treatment resin by which water contaminated with uranium, plutonium, americium, and other contaminants (e.g., lead, mercury, cadmium, zinc) can be cleaned to meet regulated discharge and drinking water standards (Horwitz 1992). Contaminated water is passed through a column of diphosphonic ion-exchange (Diphonix) resin to remove the contaminants. The Diphonix resin is commercially available and can be regenerated for reuse. Although not yet tested, this process may have applications for other radionuclides such as radium. One concern associated with radium is that the effectiveness of the treatment may be affected by water 
hardness because radium behaves similarly to calcium. Additional research is needed to determine the effectiveness of this procedure for treating NORM-contaminated produced water.

\subsubsection{Volume-Reduction Treatment}

EXXON Chemical Company and Rio Linda Chemical Company recently developed a treatment method that reduces the volume of NORM-contaminated sludge by as much as $75-80 \%$ (Callon 1992). The contaminated sludge is chemically treated to isolate the produced solids from emulsions and hydrocarbons; the solids are then segregated by size fraction. In general, this method concentrates the radioactivity in the finer fractions, producing gravel and sand fractions that are largely free of NORM contamination, and silt and clay fractions that have somewhat higher levels of NORM contamination than the original solids. This method was also tested on NORM-contaminated pipe scale but with greatly reduced efficiency; treatment reduced pipe scale by only $10 \%$. 


\section{FATE, TRANSFER, AND RISK ASSOCIATED WITH NORM}

A number of studies have evaluated the fate and transfer of NORM in the environment; most have focused on the fate of radionuclides transported in produced water. Few human health risk assessments have been conducted specifically for oil and gas NORM contamination. Additional studies are needed to facilitate the development of appropriate NORM regulations.

\subsection{ENVIRONMENTAL FATE AND TRANSFER}

When NORM-contaminated produced water is discharged to seawater, the dissolved radium equilibrates with the water, suspended solids, and sediment. Most radium ions bond with available sulfates to form soluble $\mathrm{RaSO}_{4}$; less than $13 \%$ of the dissolved radium exists as single ions, and, as a result, little radium is available for absorption by sediments (Snavely 1989). In addition, sediment absorption of radium decreases as water salinity increases. Marsh sediments near an outfall that had discharged an average of 17,000 barrels of produced water per day, containing an estimated average of $180 \mathrm{pCi} / \mathrm{L}$ of $\mathrm{Ra}-226$ and $90,000 \mathrm{mg} / \mathrm{L}$ of TDS, absorbed a maximum of only $7.5 \mathrm{pCi} / \mathrm{g}$ of Ra-226 and an average of only $3.5 \mathrm{pCi} / \mathrm{g}$ of Ra-226. This average value is low compared with some sea sediments that contain as much as $17 \mathrm{pCi} / \mathrm{g}$ of naturally occurring radium. Farther from the outfall, as water salinity became diluted by the fresher water of the marsh, radium absorption did not increase because total radium content also was diluted.

In contrast to the low concentrations reported by Snavely, Hanan (1981) observed Ra-226 concentrations in sediments adjacent to a large produced water discharge that were twice that of Ra-226 concentrations in a nearby control site. The disparity between these two studies may be attributable to the fact that radium concentrations in the vicinity of coastal discharges appear to be affected by daily and seasonal fluctuations in salinity, rainfall, runoff, tides, and sediment dispersal (Landa and Reid 1982).

If barium ions are present, produced water mixed with seawater will precipitate $\mathrm{BaSO}_{4}$ crystals that accumulate in sea floor sediments. If radium ions also are present, they will coprecipitate with the barium. The radium content of $\mathrm{BaSO}_{4}$ precipitated near produced water outfalls has not been determined; however, $\mathrm{BaSO}_{4}$ in sea sediments removed from the vicinity of oil and gas operations has been found to contain $600 \mathrm{pCi} / \mathrm{g}$ of radium (Snavely 1989).

When NORM-contaminated water is discharged to surface soils, radium typically is absorbed rapidly by the soil (Snavely 1989). In general, clay particles have the highest absorption capacity for radium, and smaller soil particles absorb the greatest amount of radium. When absorbed by humus and peat, radium becomes permanently bound. This high absorption rate results in very low radium infiltration rates through soil of approximately $1 \mathrm{ft} / 1,000 \mathrm{yr}$. According to Snavely, contamination of a potable USDW by a surface source requires acidic leachate, porous overburden, and a shallow aquifer depth. Even if radium is 
discharged or migrates into a freshwater aquifer, it is not very mobile in the groundwater because freshwater formations have a high absorption capacity for radium.

Most biota, with the exception of marine plankton, reject radium in favor of calcium (Snavely 1989). Humans reject approximately $98 \%$ of their radium intake; terrestrial plants, 50-95\%; wetland plants, 94\%; and terrestrial herbivores, $90 \%$. By contrast, marine plankton reject only $20 \%$ of their radium intake. When metabolized, most radium behaves like calcium and accumulates in an organism's skeleton or shell. In oysters, $90 \%$ of absorbed radium is found in the shells. In fish, $80-90 \%$ accumulates in the bones; in humans, $87 \%$ accumulates in the skeleton. Most aquatic plants and animals accumulate radium over time, and, as a result, the concentrations of radium in these biota will be greater than the concentrations of radium in the water in which they live. This ratio, called the bioaccumulation or concentration factor, is subject to variations in water radium concentrations that may be affected by rainfall, tidal fluctuations, or changes in the discharge. Reported concentration factors for marine animals are quite variable: in fish muscles, the reported factors range from 0 to 950; in fish bones, from 150 to 700; in mollusk soft parts, from 20 to 570; and in the edible parts of crustaceans, from 20 to 360 (BNL 1992).

\subsection{HUMAN HEALTH RISK ASSESSMENTS}

The hazards associated with human radiation exposure from any source depend on a variety of factors, including the type of radioactive emission, activity level, exposure pathway, and environmental setting.

\subsubsection{Types of Radioactive Emissions}

Three types of radioactive emissions occur: alpha, gamma, and beta. Alpha radiation is particulate, depositing its energy within a small volume but with very limited penetrating power. Although alpha radiation can result in more concentrated doses, minimal shielding can provide protection. The greatest exposure pathway of concern related to alpha radiation usually is through inhalation or ingestion. Gamma radiation is electromagnetic, capable of penetrating deeply into materials but with a more diffuse distribution. Although the diffuse distribution results in a lower dose, the penetrating power of gamma radiation can result in exposures over great distances if the source is not adequately shielded. Therefore, in addition to inhalation and ingestion, external exposure to gamma radiation is a critical pathway. Beta radiation is somewhat intermediate to alpha and gamma radiation in terms of penetrating power; exposure pathways of concern related to beta radiation include inhalation, ingestion, and dermal contact.

\subsubsection{Radiation Exposure Limits}

Conceptually, there are acceptable levels of radiation exposure below which there are no undue human health risks. Radiation exposure limits established by federal regulations 
and guidelines for other waste types should be applicable to NORM-contaminated oil and gas wastes. Limits have been established or recommended for radionuclide concentrations in drinking water, radon concentrations in indoor air, and total external exposure.

Radium concentrations in drinking water are limited to $5 \mathrm{pCi} / \mathrm{L}$ (40 CFR 141). A proposed rulemaking would raise the radium standard to $20 \mathrm{pCi} / \mathrm{L}$ and establish a drinking water standard of $300 \mathrm{pCi} / \mathrm{L}$ for radon. ${ }^{2}$

Average indoor radon concentrations are approximately $2 \mathrm{pCi} / \mathrm{L}$ (Nero et al. 1986). The EPA (1986) recommends additional testing and, possibly, remediation efforts when indoor radon concentrations are greater than $4 \mathrm{pCi} / \mathrm{L}$. By deducting the average background radon concentrations from the EPA's recommended action level, the exposure limit attributable to radon release from oil and gas NORM (or any other radon source) should be approximately $2 \mathrm{pCi} / \mathrm{L}$. Baird et al. (1990) and the CRCPD (1992) recommend limiting radon emanation rates from the surface to $2 \mathrm{pCi} / \mathrm{m}^{2} / \mathrm{s}$. At licensed NORM waste disposal sites, operated in accordance with the EPA's regulations for uranium mill tailings disposal sites as specified in 40 CFR 192, surface radon flux to the atmosphere must be limited to $20 \mathrm{pCi} / \mathrm{m}^{2} / \mathrm{s}$, averaged over the disposal site over any 1 -yr period.

In accordance with 40 CFR 190.10, Environmental Standards for the Uranium Fuel Cycle, annual dose equivalents for whole-body radiation should not exceed $25 \mathrm{mrem} / \mathrm{yr}$ for any member of the general public. OSHA standards, which apply to oil and gas industry operations, limit worker exposure (Section 1.2.1).

\subsubsection{Radiation Exposure Pathways}

Radiation exposure from oil and gas NORM can occur from seven environmental pathways: radon inhalation, external gamma exposure, groundwater ingestion, surface-water ingestion, dust inhalation, food ingestion, and skin beta exposure (Baird et al. 1990). Populations at risk from exposure to NORM radiation include workers at equipment cleaning facilities, oilfield workers, workers at NORM disposal facilities, and the general public.

Workers at equipment cleaning facilities are considered to be at the greatest risk for exposure to NORM. Exposure pathways of concern are external gamma exposure, dust inhalation, and skin beta exposure. External exposure occurs when (1) the concentration of NORM inside equipment is high enough that gamma rays penetrate the equipment walls, and (2) contaminated scale and sludge are removed from the equipment, thereby eliminating the shielding factor provided by the equipment walls. Dust inhalacion is possible when dry cleaning processes are used without adequate controls. Direct contact with contaminated scale and sludge can result in skin beta exposures.

The pathway of greatest concern for oilfield workers is external gamma exposure. External exposure can occur when (1) the concentration of NORM inside equipment is high

2 Federal Register, Vol. 56, No. 138, p. 33050, July 18, 1991. 
enough that gamma rays penetrate the equipment walls, or (2) NORM-contaminated scale accumulates on the outside of casing and tubing strings (Minnaar 1992). More concentrated external gamma exposure and dust inhalation may occur when contaminated scale or sludge is cleaned from the inside surfaces of equipment during well workover operations.

Workers at NORM disposal facilities risk exposure via radon inhalation, external gamma exposure, dust inhalation, and skin beta exposure pathways. Risk is increased at facilities where NORM-contaminated waste and equipment are buried without control features (i.e., not at licensed NORM or LLW facilities) and at smelter facilities where NORM detection systems have not been installed.

The general population may risk exposure to NORM via radon inhalation, groundwater ingestion, surface-water ingestion, and food ingestion. Improper disposal of NORM-contaminated scale and sludge may lead to soil and water contamination and to higher indoor radon levels in nearby buildings (EPA 1991). Ingestion of food grown in contaminated soils or seafood harvested in areas contaminated by produced water outfalls may result in radiation exposure. A recent risk assessment for radium discharged in produced waters indicated a potential risk of exposure exists for an individual who ingests large amounts of seafood harvested near a produced water discharge point over a lifetime (BNL 1992).

\subsubsection{Radiological Risk Assessment of Disposal Options}

An API study of management and disposal options analyzed the radiological risk associated with disposing of NORM-contaminated scale, sludge, and equipment by a number of disposal methods in different environmental settings (Baird et al. 1990). The study identified maximum concentrations of NORM that could be handled safely by each disposal alternative without exceeding any radiation exposure limits. Maximum concentrations were expressed in terms of total radium for scale, sludge, and production equipment and $\mathrm{Pb}-210$ for gas processing equipment. Limits for radiation exposures were defined from exposure limit criteria developed for corresponding radiation from other related sources. Seven environmental pathways were considered: radon inhalation, external gamma exposure, groundwater ingestion, surface-water ingestion, dust inhalation, food ingestion, and skin beta exposure.

For scale and sludge, 12 disposal methods were analyzed: landspreading, landspreading with dilution by the top 8 in. of soil, abandonment of surface (line) pipe, burial with unrestricted site use, burial at a commercial oil industry waste facility with dilution by other wastes, burial at a licensed NORM disposal facility, burial at an LLW disposal facility, burial in surface mines, disposal in a plugged and abandoned well, underground injection below USDWs in accordance with UIC Program regulations, hydraulic fracturing into a formation below USDWs, and injection into salt dome cavities. For contaminated equipment, the disposal options analyzed included the burial alternatives listed above as well as smelting and release for general use in a dwelling. 
The study by Baird et al. (1990) determined that certain pathway parameters varied with changes in geohydrologic conditions (e.g., humidity/aridity, permeability). These parameters include radon diffusion coefficients, water infiltration rates, radium transit times in groundwater, lead transit times in groundwater, soil erosion rates, and river flow rates. For most disposal options, maximum NORM concentration limits were lowest in arid, permeable sites. The results of this study, summarized in Table 3, reflect the limits for arid, permeable sites.

Baird et al. concluded that, for scale and sludge, burial with unrestricted site use and disposal by the landspreading options provided the least isolation of radionuclides and, therefore, had the lowest maximum concentration limits. The environmental pathway of greatest concern associated with unrestricted burial is radon inhalation; with landspreading, it is external gamma exposure. Disposal in salt dome cavities provided the greatest isolation, although all deep, subsurface disposal options had maximum limits of $100,000 \mathrm{pCi} / \mathrm{g}$ or higher. The environmental pathway of greatest concern associated with deep, subsurface disposal is ingestion of contaminated groundwater. Shallow burial at controlled facilities exhibited a range of intermediate concentration limits, with radon inhalation posing the pathway of greatest concern.

TABLE 3 Maximum Concentration Limits for Disposal of NORM (pCi/g)

\begin{tabular}{|c|c|c|c|c|}
\hline \multirow[b]{2}{*}{ Disposal Alternative } & \multirow{2}{*}{$\begin{array}{l}\text { Sludge, } \\
\text { Radium }\end{array}$} & \multirow{2}{*}{$\begin{array}{c}\text { Scale, } \\
\text { Radium }\end{array}$} & \multicolumn{2}{|c|}{ Equipment } \\
\hline & & & Radiuma & $\mathrm{Pb}-210$ \\
\hline Landscaping & 120 & 120 & $\mathbf{N A}^{\mathrm{b}}$ & NA \\
\hline Landspreading with dilution & 260 & 260 & NA & NA \\
\hline Abandoned surface pipe & 2,700 & 6,700 & N.A & NA \\
\hline Burial with unrestricted site use & 29 & 130 & 440 & None \\
\hline Commercial oil industry waste facility & 410 & 1,800 & 6,200 & None \\
\hline NORM disposal facility & 1,000 & 4,500 & 68,000 & None \\
\hline LLW disposal facility ${ }^{\mathrm{C}}$ & 50,000 & 50,000 & 100,000 & None \\
\hline Surface mine $e^{c}$ & 3,500 & 100,000 & 100,000 & None \\
\hline Plugged and abandoned well ${ }^{c}$ & 100,000 & 100,000 & 100,000 & None \\
\hline Underground injection ${ }^{c}$ & 100,000 & 100,000 & NA & NA \\
\hline Hydraulic fracturing ${ }^{c}$ & 100,000 & 100,000 & NA & NA \\
\hline Salt dome $e^{c}$ & 100,000 & 100,000 & NA & NA \\
\hline Release for general use in a dwelling & $\mathbf{N A}$ & NA & 100 & NA \\
\hline Smelter & NA & NA & 40,000 & 30,000 \\
\hline
\end{tabular}

a Total radium concentration.

b Not applicable.

c If limit exceeds $100,000 \mathrm{pCi} / \mathrm{g}$, it is reported as $100,000 \mathrm{pCi} / \mathrm{g}$.

Source: Baird et al. (1990). 
For radium-contaminated equipment, release for use in dwellings has the lowest maximum concentration limit, based on the external gamma exposure pathway. Radium concentration limits for burial options range from 440 to $100,000 \mathrm{pCi} / \mathrm{g}$ or higher; burial with unrestricted site use provides the least isolation. The limiting exposure pathways associated with the burial options are the same as for scale and sludge. For Pb-210-contaminated equipment, Baird et al. detected no concentration limits for disposal by burial. For release to a smelter, the radium concentration limit is $40,000 \mathrm{pCi} / \mathrm{g}$, and the $\mathrm{Pb}-210$ limit is $30,000 \mathrm{pCi} / \mathrm{g}$. 


\section{CONCLUSIONS}

On the basis of a review of available data describing NORM occurrence in the oil and gas industry, preliminary conclusions can be drawn regarding the need for additional research, the need for the development of NORM regulatory programs, and the potential impact of NORM regulation on the oil and gas industry.

\subsection{ADDITIONAL RESEARCH NEEDS}

To date, most NORM studies have been preliminary in nature and do not provide adequate data to describe the occurrence and distribution of NORM throughout the oil and gas industry. Additional studies are needed to describe radionuclide concentrations in NORM and their geographic distribution. In addition, a study should be conducted to determine whether any correlation exists between the occurrence of NORM and specific hydrocarbonproducing formations or different extraction methods (Raloff 1991).

The recent detection of NORM-contaminated scale on the outside of downhole casing and tubing in Michigan should also be investigated (Minnaar 1992). Because most NORM not maintained in the produced water stream seem to accumulate inside equipment, the walls of the equipment may protect workers and the general public from radiation exposure to some extent. If accumulation of NORM on the outside of casing is more widespread than previously understood, assumptions about the risk of radiation exposure may be incorrect.

Risk assessments have not fully characterized the hazards posed by NORM to industry workers or the general public. The fate of NORM in the environment has not been adequately characterized (most studies focus on restricted marine and estuary systems), and suitable disposal alternatives have not been identified with any certainty. In addition to evaluating the risk associated with existing oil and gas operations, investigations also should study the risk posed by past activities and their associated contamination.

Additional research is needed to identify economic treatment technologies for NORMcontaminated wastes. Emphasis should be placed on developing technologies that minimize waste volumes and radioactivity levels.

A number of NORM studies that may address the existing research gaps have been proposed or are currently underway (White 1992):

- Hydrochemical and production controls of NORM in oil and gas field operations. The U.S. Department of Energy (DOE) is funding a study by the Bureau of Economic Geology at the University of Texas to determine where NORM wastes are likely to exist in the oil and gas industry on a basinwide and well-by-well scale. The purpose of this study is to identify those reservoir characteristics and production techniques that control NORM occurrence. The study will sample 
produced water and NORM-contaminated wastes from all major reservoir types in Texas.

- Range of radionuclide concentrations in NORM-contaminated wastes. Idaho National Engineering Laboratory, in collaboration with API and with funding from DOE, is determining the range of radionuclide concentrations present in NORM-contaminated oil and gas wastes and equipment. This study expands on the study by Otto (1989). External gamma radiation measurements will be taken, and samples of oil and gas waste will be analyzed for radionuclide content.

- Offshore fate and effects. The EPA Office of Water and Office of Radiation Programs cosponsored a field survey of three production platforms in the Gulf of Mexico to collect radionuclide data from sediments, seawater, produced water, and caged clams.

- Preliminary risk analysis on NORM in the production of crude petroleum. Louisiana State University, with funding from API, is assessing the level of NORM at selected sites to determine the need for future risk assessments. The study is evaluating radiation doses to workers and the general public associated with routine production operations, operation of pipe yards and warehouses, tubular cleaning operations, and abandoned reserve pits.

- NORM risk assessment for radium discharged offshore in produced waters. Brookhaven National Laboratory, with funding from DOE, is assessing the health risks associated with the ingestion of radium from fish and shellfish harvested near offshore discharges of produced water. The interim results of this study are discussed briefly in Section 5.2.3; a more comprehensive, probabilistic assessment was scheduled for completion in October 1992.

- Risk assessment of management and disposal options for oilfield wastes and piping contaminated with NORM in Louisiana. The EPA Office of Radiation Programs and Louisiana Radiation Protection Division cosponsored a risk assessment of disposal options for NORMcontaminated wastes and equipment. The report summarizing this assessment discusses the risk associated with both downhole disposal and near-surface disposal alternatives. Release of this report is imminent (Bohlinger 1992).

- Scrap metal recycling of oil and gas equipment contaminated with NORM. The Petroleum Environmental Research Forum is assessing the safety, practicality, and economics of scrap metal recycling as an option for the environmentally sound disposition of NORM-contaminated oil and gas production and processing equipment. 


\subsection{DEVELOPMENT OF NORM REGULATIONS}

A review of available data shows that the occurrence and radioactivity of oil and gas NORM may be significant enough to warrant more stringent regulations. However, additional research (Section 6.1) is needed to ensure that the NORM regulatory programs adequately protect workers and the general public without burdening the oil and gas industry unnecessarily.

In developing the AEA, the federal government's concern with radioactive materials focused solely on source materials, special nuclear materials, and by-product materials associated with fission reactors and atomic weapons. A subsequent amendment of the AEA included uranium mill tailings (a source of NORM) within by-product materials. All other radioactive material is regulated piecemeal by federal and state environmental regulatory programs.

For the most part, federal regulations have not been developed for any industryspecific NORM sources, except uranium mill tailings. Radium concentrations in some petroleum industry wastes are similar to radium concentrations in uranium mill tailings; however, neither the EPA nor the NRC has indicated an intent to extend the regulations governing uranium mill tailings to oil and gas NORM. Several federal regulations have established limits on radionuclide concentrations in the environment, but these regulations are not specific to NORM, and they are largely inapplicable. Although any one of the federal environmental regulations could be amended to include oil and gas NORM, this change does not seem likely in the near future.

In the absence of federal regulations, many states have begun to develop NORM regulatory programs. Although this process will allow state agencies the greatest flexibility for developing regulations appropriate to oil and gas operations within their state, many states probably do not have adequate resources for this effort. National leadership at the federal level should aim to provide guidance for the development of state-run programs. Federal guidance would alleviate the strain on state resources without necessarily compromising the applicability of the regulations. One state regulator suggested that the states need this type of guidance and that it would be most useful if provided in the form of one regulatory program rather than as components of existing, fragmented environmental regulations.

\subsection{POTENTLAL IMPACTS ON THE OIL AND GAS INDUSTRY}

The greatest impact to the petroleum industry as a result of the development of NORM regulatory programs will be increased costs associated with the disposal of NORM as radioactive waste. The costs associated with disposal of NORM will depend on the disposal alternatives allowed. For example, if disposal via underground injection is restricted in favor of disposal at licensed NORM facilities, the generator's costs will be far more substantial. Additional requirements for licensing and reporting, worker protection, training, and monitoring programs also will increase the financial burden on the petroleum industry. If 
the petroleum industry is required to clean up NORM contamination associated with past activities, the impact will be excessive.

The impact of increased regulation can be minimized if NORM regulations are developed with realistic, industry-specific standards. To facilitate this development, additional research to characterize the occurrence, activity, and associated risk of NORM (Section 6.1) is critical. 


\section{REFERENCES}

API, 1988, NORM Regulatory Analysis Report, Task Group on Regulatory Analysis, American Petroleum Institute, Washington, D.C.

API, 1992, Bulletin on Management of Naturally Occurring Radioactive Materials (NORM) in Oil and Gas Production, API Bulletin E2, American Petroleum Institute, Washington, D.C.

Baird, R.D., et al., 1990, Management and Disposal Alternatives for NORM Wastes in Oil Production and Gas Plant Equipment, prepared for American Petroleum Institute, Dallas, Texas.

BNL, 1992, Human Health Risk Assessment for Radium Discharged Offshore in Produced Waters (Interim Report), informal report BNL-47390, prepared by Brookhaven National Laboratory, Upton, N.Y., for U.S. Department of Energy, Metairie Site Office.

Bohlinger, H., 1992, personal communication from Bohlinger (Radiation Protection Division, Louisiana Office of Air Quality, Baton Rouge, La.), to K.P. Smith (Argonne National Laboratory, Lakewood, Colo.), Dec. 7.

Brookins, D.G., 1984, Geochemical Aspects of Radioactive Waste Disposal, Springer-Verlag, New York, N.Y.

Callon, D., 1992, personal communication from Callon (EXXON Company USA, New Orleans, La.), to K.P. Smith (Argonne National Laboratory, Lakewood, Colo.), Aug. 21.

CRCPD, 1990, Part N - Regulation and Licensing of Naturally Occurring Radioactive Materials (NORM), proposed draft, Conference of Radiation Control Program Directors, Inc., Frankfort, Ky.

CRCPD, 1992, Report of the E-4 Committee on NORM Contamination and Decommissioning/ Decontamination - Report 3, Conference of Radiation Control Program Directors, Inc., Frankfort, Ky.

Engineering Enterprises, Inc., 1989, Survey of State Class II UIC Programs, Task 4 Mechanical Integrity Testing, Background Paper, prepared by Engineering Enterprises, Inc., Norman, Okla., for the Underground Injection Control Branch, U.S. Environmental Protection Agency, Contraci No. 68-03-3416, Washington, D.C.

EPA, 1986, A Citizen's Guide to Radon, OPA-86-004, Office of Air and Radiation, U.S. Environmental Protection Agency, Washington, D.C.

EPA, 1991, DRAFT Diffuse NORM Waste Characterization and Preliminary Risk Assessment, ANR-460, Office of Radiation Programs, U.S. Environmental Protection Agency, Washington, D.C. 
ERT, 1988, Exploration and Production Industry Associated Wastes Report, prepared for the American Petroleum Institute, Washington, D.C., May.

Hanan, M.A., 1981, Geochemistry and Mobility of Radium from Oil-Field Production Brine, Plaquemines Parish, Louisiana, Master's thesis, University of New Orleans, New Orleans, La.

Horwitz, P., 1992, personal communication from Horwitz (Argonne National Laboratory, Argonne, Ill.), to K.P. Smith (Argonne National Laboratory, Lakewood, Colo.).

Landa, E.R., and D.F. Reid, 1982, "Sorption of Radium-226 from Oil-Production Brine by Sediments and Soils," Environmental Geology 5(1):1-8.

Louisiana Department of ELivironmental Quality, 1992, Regulation and Licensing of Naturally-Occurring Radioactive Materials (NORM), Title 33 Environmental Quality, Part XV, Radiation Protection.

Michigan Department of Natural Resources and Michigan Department of Public Health, 1991, Naturally Occurring Radioactive Material (NORM) at Michigan Oil and Gas Field Sites: Preliminary Survey Results, Lansing, Mich.

Michigan Department of Public Health, 1992, Interim Standards for the Control of NORM Associated with the Oil and Gas Industry in Michigan, Lansing, Mich., April 13.

Minnaar, D., 1992, personal communication from Minnaar (Division of Radiological Health, Michigan Department of Public Health, Lansing, Mich.), to K.P. Smith (Argonne National Laboratory, Lakewood, Colo.), Aug. 6.

Nero, A.V., et al., 1986, "Distribution of Airborne Radon-222 Concentrations in U.S. Homes," Science 234:992-997.

Nielson, K.K., et al., 1988, Safety Analysis for the Disposal of Naturally-Occurring Radioactive Materials in Texas, RAE-8818-1, prepared by Rogers \& Associates Engineering Corp., for the Texas Low-Level Radioactive Waste Disposal Authority.

Otto, G.H., 1989, A National Survey on Naturally Occurring Radioactive Materials (NORM) in Petroleum Producing and Gas Processing Facilities, prepared for American Petroleum Institute, Dallas, Texas.

Raloff, J., 1991, "NORM: The New Hot Wastes," Science News 140(17):264-267.

Snavely, E.S., 1989, Radionuclides in Produced Water - A Literature Review, American Petroleum Institute Publication No. 4504, Dallas, Texas.

Texas Department of Health, 1992, Licensing of Naturally Occurring Radioactive Materials (NORM), proposed rule, Texas Regulations for Control of Radiation, Part 46. 
White, G.J., 1992, Naturally Occurring Radioactive Materials (NORM) in Oil and Gas Industry Equipment and Wastes - A Literature Review, prepared for Assistant Secretary for Fossil Energy, U.S. Department of Energy, Contract No. DE-AC07-76ID01570, Idaho National Engineering Laboratory, Idaho Falls, Idaho. 


\section{DISTRIBUTION FOR ANL/EAIS-7}

\section{Internal}

ANL Patent Department

K.S. Macal (5)

ANL Technical Publications Services

M. Clemmons

K.P. Smith (52)

\section{External}

U.S. Department of Energy Office of Scientific and Technical Information (12)

Manager, U.S. Department of Energy Chicago Field Office

ANL-E Libraries

ANL-W Library 


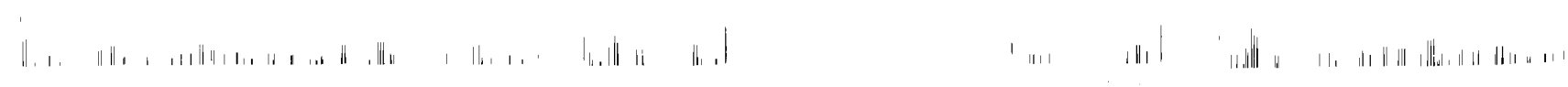

1
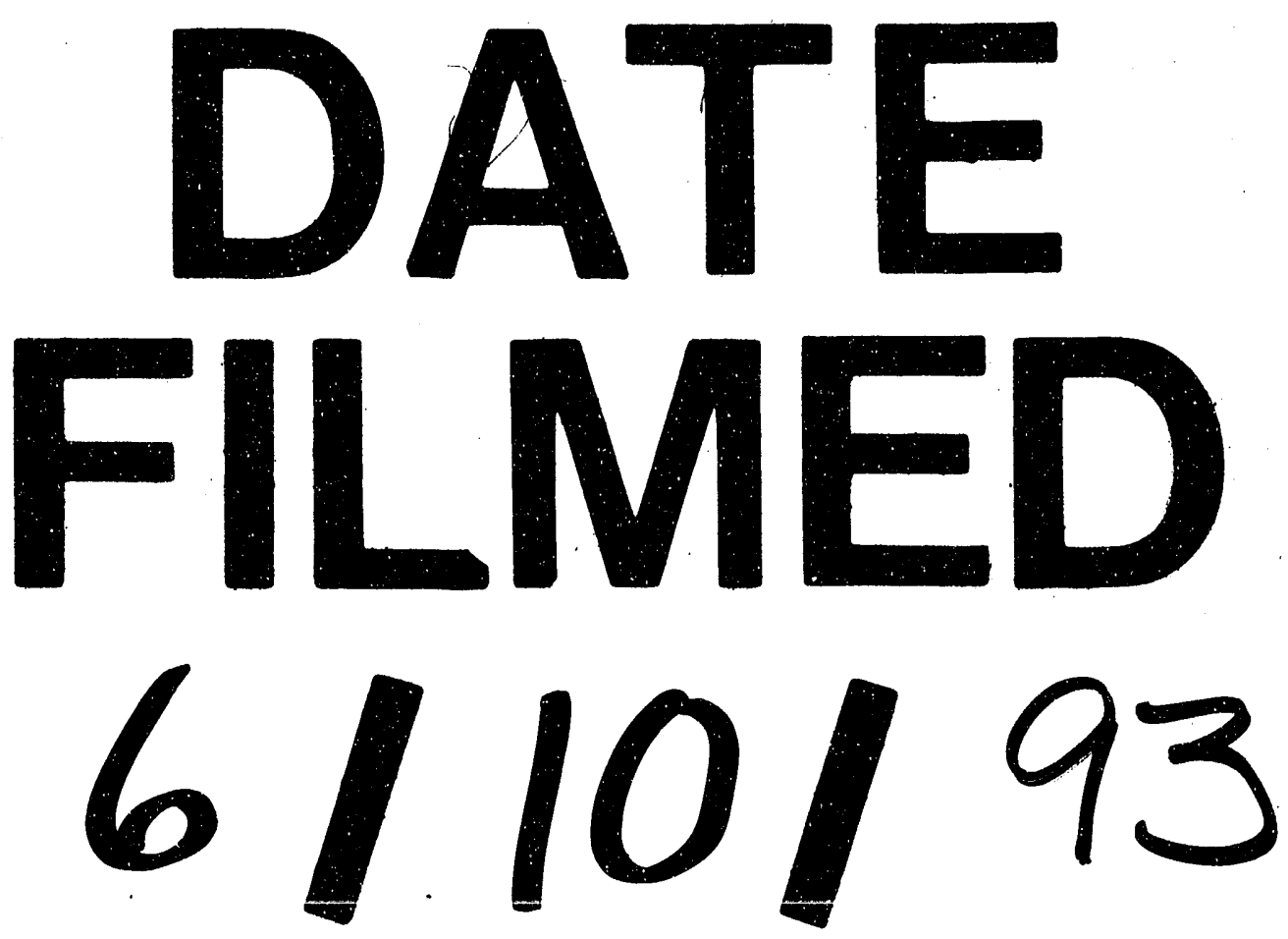


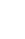

